[Agr. Biol. Chem., Vol. 32, No. 10, p. 1220 1227, 1968]

\title{
Studies on Vitamin $\mathrm{B}_{6}$ Metabolism in Microorganisms
}

\author{
Part VII. Microbial Phosphorylation of Vitamin $B_{6}$ through a New \\ Phosphotransferring Reaction (3) \\ Crystallization and Characterization of Acid Phosphatase Having \\ Pyridoxine-Phosphorylating Activity
}

\author{
By Yoshiki Tani, Tatsurokuro TochikURa, Hideaki Yamada ${ }^{\star}$ and Koichi Ogata \\ Department of Agricultural Chemistry, Kyoto University, Kyoto \\ *Research Institute for Food Science, Kyoto University, Kyoto \\ Received April 23, 1968
}

\begin{abstract}
The enzyme which catalyzed the transphosphorylation of pyridoxine accompanying with the hydrolyzation of phosphoryl donor substrates was purified and crystallized from the cell free extract of Escherichia freundii K-1. The purification procedures involved heat treatment, ammonium sulfate fractionation and DEAE-cellulose, hydroxylapatite, and CM-sephadex column chromatographies. The crystalline enzyme showed the sedimentation coefficient of $7.5 \mathrm{~S}$ and the diffusion coefficient of $6.15 \times 10^{-i} \mathrm{~cm}^{2} / \mathrm{sec}$. The molecular weight was calculated to be 120,000 . Several properties of the purified enzyme were also investigated. It was recognized that the transphosphorylation of pyridoxine might be catalyzed by the action of acid phosphatase.
\end{abstract}

The transphosphorylation reactions catalyzed by phosphatases have been demonstrated as their intrinsic functions ${ }^{11}$ Though it is considered to be not necessary to assume the existence of a separate class of phosphotransferase in the phosphatase preparation ${ }^{21}$, the detailed mechanism on the function still remains to be elucidated.

In the previous paper ${ }^{31}$, several properties of the enzyme, which catalyzed the phosphoryl group transfer from various organic phosphates to vitamin $B_{6}$, did not depend on ATP, were investigated with the partially purified enzyme from Escherichia freundii K-1.

The following abbreviations are used; pyridoxine$\mathrm{P}$, pyridoxine $5^{\prime}$-phosphate; $p$-NPP, $p$-nitrophenylphosphate; $p$-NP, $p$-nitrophenol.

1) B. Axelrod, Advan. Enzymol., 17, 159 (1956)

2) M. Dixon and E. C. Webb, Brit. Med. Bull., 9, 110 (1953).

3) K. Ogata, Y. Tani and T. Tochikura, Agr. Biol. Chem., 32, 1212 (1968).
The enzyme preparation also showed the high phosphatase activity at the same acidic $\mathrm{pH}$. During the course of further investigation on the transphosphorylation, the crystalline enzyme having both the phosphotransferase and phosphatase activities was obtained from the bacterial cell extract.

The present paper will report the studies on the purification, crystallization, and some of the properties of the enzyme. The results indicate that the phosphotransferase activity is functioned by an acid phosphatase.

A part of this work has been briefly reported elsewhere ${ }^{41}$

\section{MATERIALS AND METHODS}

Microorganism and cultures. Escherichia freundii $\mathrm{K}-1$, which was isolated from soil and identified in

4) Y. Tani, T. Tochikura, H. Yamada, and K. Ogata, Biochem. Biophys. Res. Commn., 28, 769 (1967). 
the previous work ${ }^{3}$, was used throughout this work. The culture medium for the organism consisted of $1.5 \mathrm{~g}$ peptone, $1.0 \mathrm{~g}$ glucose, $0.2 \mathrm{~g}$ yeast extract, $0.5 \mathrm{~g}$ $\mathrm{K}_{2} \mathrm{HPO}_{4}, 0.1 \mathrm{~g} \mathrm{KH}_{2} \mathrm{PO}_{4}, 0.2 \mathrm{~g} \mathrm{NaCl}$ and $0.02 \mathrm{~g} \mathrm{MgSO}_{4}$. $7 \mathrm{H}_{2} \mathrm{O}$ in $100 \mathrm{ml}$ of tap water, $\mathrm{pH} 7.0$. The bacterial cultivation was made aerobically for $20 \sim 25 \mathrm{hr}$ at $28^{\circ} \mathrm{C}$ with 2 liter shaking flask contained $500 \mathrm{ml}$ of the medium.

Activity measurement. Enzymatic activity was routinely measured in a system with a final volume of $3 \mathrm{ml}$ containing $10 \mu$ moles of pyridoxine, $50 \mu$ moles of $p$-NPP, $200 \mu$ moles of Tris-maleate buffer, $\mathrm{pH} 6.0$, and enzyme. Incubation was carried out for $30 \mathrm{~min}$ at $37^{\circ} \mathrm{C}$ and the reaction was stopped by heating for $10 \mathrm{~min}$ in a boiling water bath. Any precipitate formed was removed by centrifugation and the supernatant fluid was used for the determination of pyridoxine-P, $p$-NP and inorganic phosphorus. When the heat-labile substrates were used in the assay, the control tube contained substrate and the buffer. After the $30 \mathrm{~min}$ incubation period, the assay was performed in the same manner.

Specific activity of the enzyme is expressed as units per mg of protein where one unit is defined as the amount of protein that forms one $\mu$ moles of $p$ $\mathrm{NP}$ in $30 \mathrm{~min}$ at $37^{\circ} \mathrm{C}$.

Analytical methods. $p$-NP, pyridoxine-P and protein were determined as noted in previous paper ${ }^{3}$. Inorganic phosphorus was determined according to the method of Takahashi5). Sedimentation velocities were measured with a Spinco model $\mathrm{E}$ ultracentrifuge operating at $59,780 \mathrm{rev} . / \mathrm{min}$. The ultracentrifuge runs for the diffusion constant was made in the Spinco model E ultracentrifuge operating at 6995 $\mathrm{rev} / \mathrm{min}$. The temperature of the ultracentrifugation was maintained at 21.5 and $12.8^{\circ} \mathrm{C}$, respectively.

Chemicals. Hydroxylapatite was prepared according to the method of Tiselius et al. ${ }^{61}$ Other chemicals were used the same as in the previous work ${ }^{3}$.

\section{RESULTS}

Purification of acid phosphatase having pyridoxine-phophorylating activity

All operations were performed at $0-5^{\circ} \mathrm{C}$ throughout the purification procedures.

5) Y. Takahashi, Seikagagu, 26, 690 (1951).

6) A. Tiselius, S. Hjerten and O. Levin, Arch. Biochem. Biophys., 65, 132 (1956).
Setp I. Preparation of crude extract. The crude extract of Escherichia freundii K-1 was prepared from cells cultivated on 300 liters of the culture medium. The cells were harvested by centrifugation and washed twice with deionized water. The washed cells were suspended in $0.01 \mathrm{~m}$ potassium phosphate buffer, $\mathrm{pH} 7.0$, and disrupted with Kaijo-Denki 19 $\mathrm{Hz}$ ultrasonic oscillator. The cell debris was removed by centrifugation at $12,000 \times \mathrm{g}$ for $30 \mathrm{~min}$.

Step II. Heat treatment. The cell free extract was immediately heated for $10 \mathrm{~min}$ at $60^{\circ} \mathrm{C}$ in a water bath by a gentle stirring. The resulted precipitates were centrifuged off at $10,000 \times \mathrm{g}$ for $30 \mathrm{~min}$. The supernatant solution was then dialyzed against deionized water overnight.

Step III. First ammonium sulfate fractionation. To the dialyzed enzyme solution was added solid ammonium sulfate to $35 \%$ saturation, adjusting $\mathrm{pH}$ to 7.0 with $10 \%$ ammonium hydroxide solution. After stirring for $30 \mathrm{~min}$, the precipitated protein was removed by centrifugation at $10,000 \times \mathrm{g}$ for $20 \mathrm{~min}$ and discarded. The ammonium sulfate concentration was then increased to $65 \%$ saturation by further addition of solid ammonium sulfate. After stirring for $30 \mathrm{~min}$, the precipitate was collected by centrifugation at $10,000 \times \mathrm{g}$ for $20 \mathrm{~min}$. This process was repeated separately until $340 \mathrm{~g}$ of the cells as dry weight were treated and the active precipitates were combined for the further purification. The combined precipitate was dissolved in $0.01 \mathrm{~m}$ potassium phosphate buffer, $\mathrm{pH} 7.0$, the final volume was $1000 \mathrm{ml}$. The solution was then dialyzed overnight against the same buffer. The inactive precipitate appeared was removed by centrifugation at $12,000 \times \mathrm{g}$ for $20 \mathrm{~min}$.

Step IV. Protamine sulfate treatment. Hundred $\mathrm{ml}$ of freshly prepared $2.0 \%$ protamine sulfate solution neutralized with sodium hydroxide, was slowly added under stirring to $1100 \mathrm{ml}$ of the dialyzed enzyme solution from step III and allowed to stand for $15 \mathrm{~min}$. The 
precipitate formed was removed by centrifugation at $12,000 \times \mathrm{g}$ for $30 \mathrm{~min}$ and the resultant supernatant solution was dialyzed against three changes of $0.01 \mathrm{~m}$ potassium phosphate buffer, $\mathrm{pH}$ 7.0, 12 liter each, overnight under continuous stirring.

Step V. DEAE-Cellulose column chromatography. The absorbent equilibrated with 0.01 M potassium phosphate buffer, $\mathrm{pH} 7.0$, was packed into a column $3 \times 40 \mathrm{~cm}$. The enzyme solution was placed on the column and eluted with 2.5 liter of $0.01 \mathrm{M}$ potassium phosphate buffer, pH 7.0 (Fig. 1). The active fractions

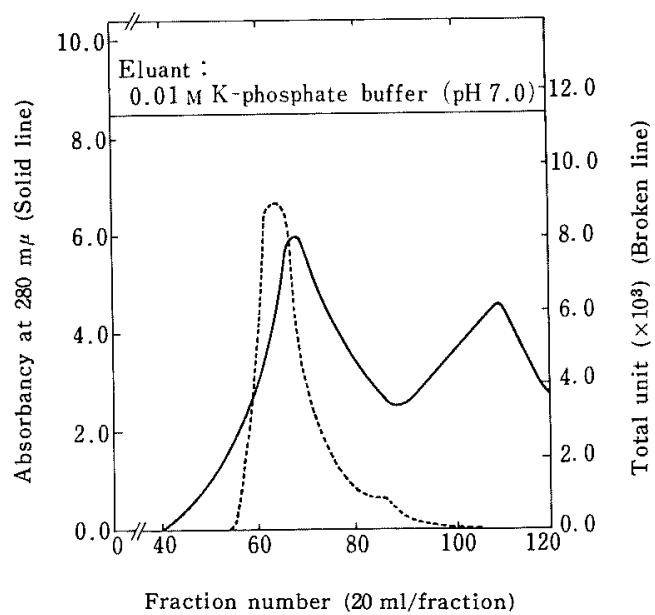

FIG. 1. Chromatography of Phosphatase on DEAECellulose Column.

Chromatography was performed as stated in the text, and the enzyme activity was assayed under the standard assay conditions.

were combined to give $860 \mathrm{ml}$ of solution and concentrated by the addition of ammonium sulfate to $80 \%$ saturation. The precipitate obtained by centrifugation at $12,000 \times \mathrm{g}$ for $30 \mathrm{~min}$ was dissolved in $0.01 \mathrm{~m}$ potassium phosphate buffer, $\mathrm{pH} 7.0$, and dialyzed overnight against 10 liters of the same buffer.

Step VI. Second ammonium sulfate fractionation. Solid ammonium sulfate to $45 \%$ saturation was added to $90 \mathrm{ml}$ of the dialyzed enzyme solution from step $\mathrm{V}$, adjusting $\mathrm{pH}$ ts 7.0 with $10 \%$ ammonium hydroxide solution After stirring for $30 \mathrm{~min}$, the precipitate wa' removed by centrifugation at $12,000 \times \mathrm{g}$ for $20 \mathrm{~min}$. The ammonium sulfate concentra tion was then increased to $55 \%$ saturation by the further addition of solid ammonium sul. fate. After stirring for $30 \mathrm{~min}$, the precipitate was collected by centrifugation at $12,000 \times g$ for $20 \mathrm{~min}$ and dissolved in a small amoun of 0.01 м potassium phosphate buffer, $\mathrm{pH} 7.0$ The fractionated solution was dialyzed against three changes of the same buffer, 5 liters each, overnight.

Step VII. Hydroxylapatite column chromatography. The dialyzed enzyme solution $(25 \mathrm{ml})$ was subjected to hydroxylapatite column chromatography. The absorbent equilibrated with $0.01 \mathrm{~m}$ sodium phosphate buffer, $\mathrm{pH} 6.8$, was used to pack a column $5 \times 5 \mathrm{~cm}$. The dialyzed enzyme was placed on the column and the column was washed with $650 \mathrm{ml}$ of $0.03 \mathrm{~m}$ of the same buffer. The enzyme was subsequently eluted with $0.1 \mathrm{M}$ of the same buffer containing $0.1 \mathrm{M}$ sodium chloride and combined to give $150 \mathrm{ml}$ of solution. The elution pattern is shown in Fig. 2. The active fraction was concentrated by the addition of ammonium sulfate to $80 \%$ saturation. The precipitate obtained by centrifugation at $12,000 \times \mathrm{g}$ for $30 \mathrm{~min}$ was dissolved in $0.01 \mathrm{~m}$ potassium phosphate buffer, $\mathrm{pH}$ 6.6, and dialyzed against two changes of the same buffer, each 5 liter, overnight.

Step VIII. CM-Sephadex column chromatography. The dialyzed enzyme solution ( 9.4 $\mathrm{ml}$ ) was subjected to CM-sephadex column chromatography. The absorbent equilibrated with $0.01 \mathrm{~m}$ potassium phosphate buffer, $\mathrm{pH}$ 6.6 , was used to pack a column $2.2 \times 90 \mathrm{~cm}$ The enzyme solution was placed on the columr and the column was washed with the same buffer. The enzyme was eluted with 0.03 « of potassium phosphate buffer, $\mathrm{pH}$ 6.6. The elution pattern is shown in Fig. 3. The activi fractions which had approximately 3000 -fok 


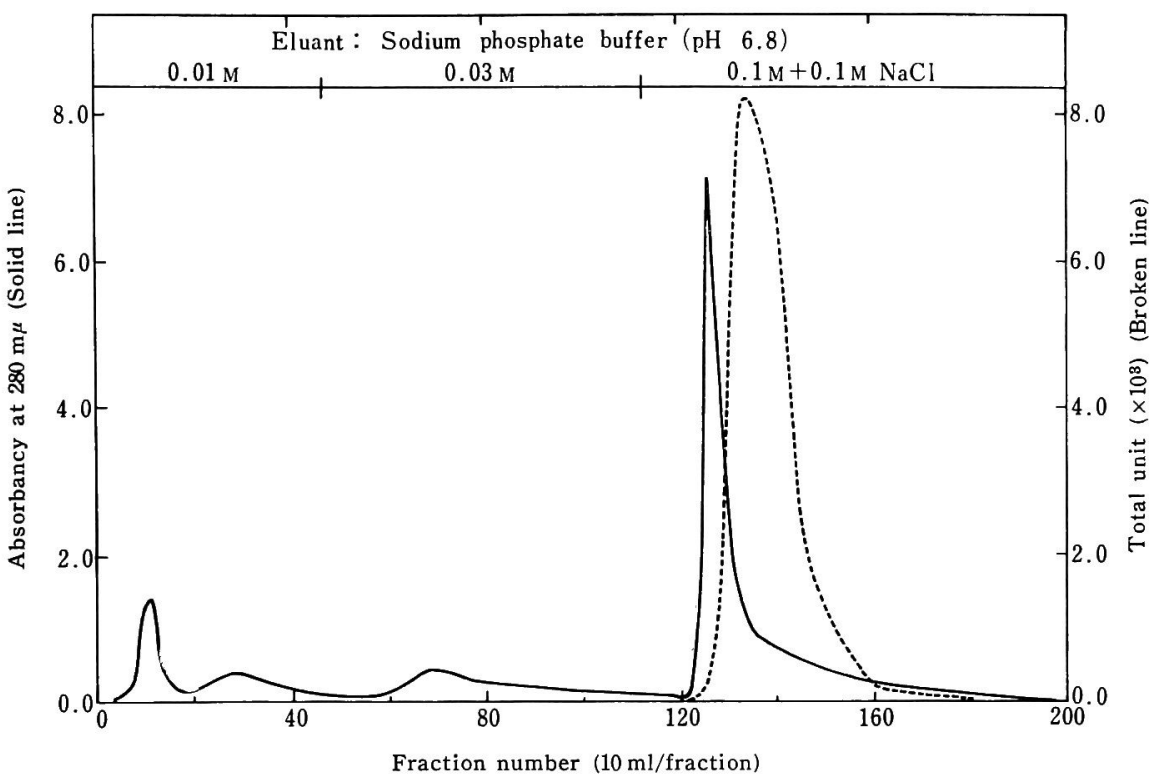

FIG. 2. Chromatography of Phosphatase on Hydroxylapatite Column.

Chromatography was performed as stated in the text, and the enzymes activity was assayed under the standard assay conditions.

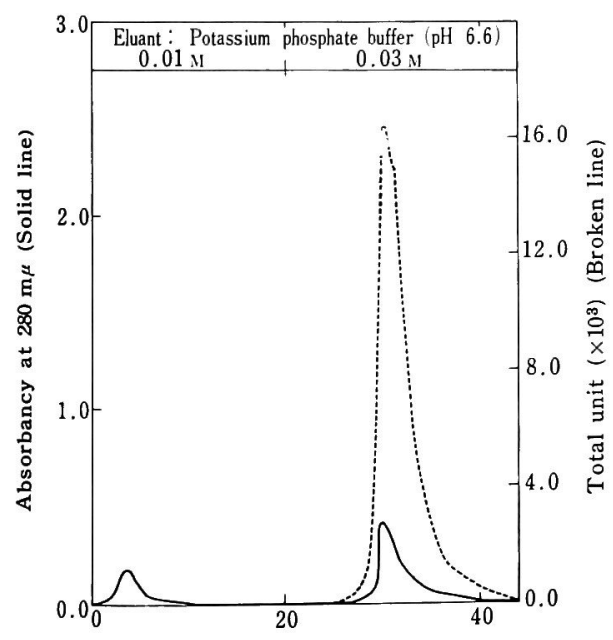

Fraction numbr (10 ml/fraction)

FIG. 3. Chromatography of CM-Sephadex Column.

Chromatography was performed as stated in the text, and the enzyme activity was assayed under the standard assay conditions.

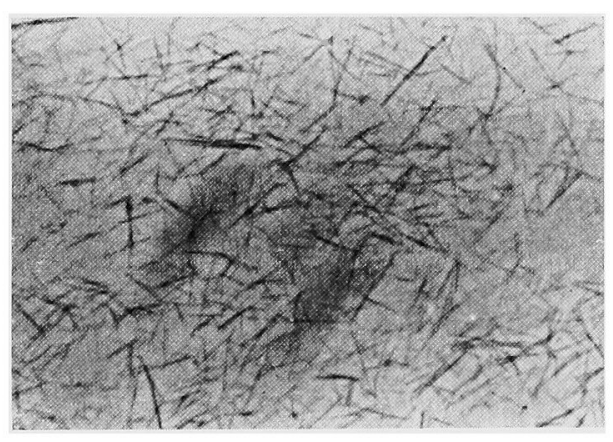

FIG. 4. Photomicrograph of Crystalline Acid Phosphatase of Escherichia freundii $\mathrm{K}-1$

specific activity to the original extract were combined to give $63 \mathrm{ml}$ of solution and precipitated by the addition of ammonium sulfate to $80 \%$ saturation.

Step IX. Crystallization. The purified enzyme preparation obtained from CM-sephadex column chromatography was used for the crystallization of the enzyme. The precipitate 
Table I. Purification of acid Phosphatase

$\begin{array}{clccrc}\text { Step } & \text { Fraction } & \begin{array}{c}\text { Total } \\ \text { protein }\end{array} & \begin{array}{c}\text { Total } \\ \text { activity }\end{array} & \begin{array}{c}\text { Specific } \\ \text { activity }\end{array} & \begin{array}{c}\text { Ratio } \\ p \text {-N/pyridoxine-P }\end{array} \\ \text { I } & \text { Cell free extract } & 343,300 \mathrm{mg} & 308,970 & 0.9 & 33 \\ \text { II } & \text { Heat treatment } & 58,200 & 302,640 & 5.2 & 35 \\ \text { III } & \text { Ammonium sulfate } & 27,500 & 299,750 & 10.9 & 35 \\ \text { IV } & \text { Protamine treatment } & 18,200 & 305,760 & 16.8 & 35 \\ \text { V } & \text { DEAE-cellulose } & 4,000 & 228,400 & 57.1 & 32 \\ \text { VI } & \text { Ammonium sulfate } & 1,420 & 116,080 & 81.7 & 33 \\ \text { VII } & \text { Hydroxylapatite } & 113 & 133,815 & 1184.2 & 32 \\ \text { VII } & \text { CM-sephadex } & 18 & 37,803 & 2716.1 & 31 \\ \text { IX } & \text { Crystallization } & 12 & 33,602 & 2800.2 & 32\end{array}$

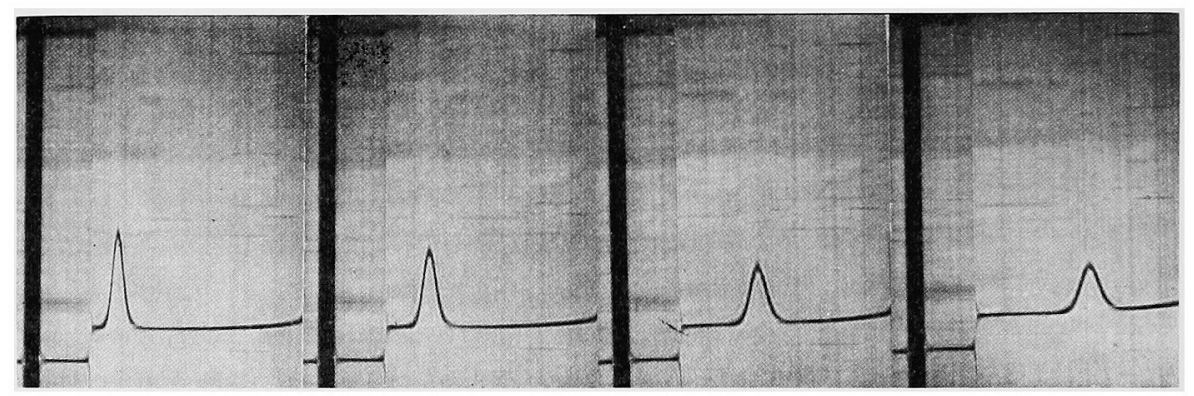

FIG. 5. Ultracentrifugal Analysis of Crystalline Acid Phosphatase

Schlieren patterns after (left to right) $8,16,32,48 \mathrm{~min}$ at $59,780 \mathrm{rpm}$ in the Spinco model $\mathrm{E}$ analytical ultracentrifuge. Protein, $0.67 \%$ in $0.01 \mathrm{M}$ potassium phosphate buffer of $\mathrm{pH} 7.0$.

was collected by centrifugation at $15,000 \times \mathrm{g}$ for $30 \mathrm{~min}$ and dissolved in a small volume of $0.03 \mathrm{M}$ potassium phosphate buffer, $\mathrm{pH}$ 7.0. The insoluble precipitate was removed by centrifugation. Solid ammonium sulfate was added gradually to the supernatant solution until the solution became faintly turbid. The turbid suspension was left in the refrigerator for about one week. Fig. 4 is a photomicrograph of crystalline acid phosphatase having pyridoxine-phosphorylating activity which appeared as highly refractive needles.

The results of the purification procedure are summarized in Table I.

Properties of the enzyme

Ultracentrifuge analysis. The analysis of the crystalline enzyme preparation showed a single and symmetric schlieren peak in the ultracentrifuge as shown in Fig. 5. The sedimentation coefficient in water at $20^{\circ}$ $\left(s_{20, \mathrm{w}}\right)$ was found to be 7.5 Svedberg constan when the protein concentration of $7 \mathrm{mg} \mathrm{pr}$ $\mathrm{ml}$ was used in $0.03 \mathrm{~m}$ potassium phospha buffer, $\mathrm{pH}$ 7.0, assuming values found $\mathrm{ft}$ most proteins of $\mathrm{V}$, the partial specific volun of the enzyme, equal to 0.75 . The diffusic coefficient in water at $20^{\circ} \mathrm{C}\left(D_{20, w}\right)$ was foun to be $6.15 \times 10^{-7} \mathrm{~cm}^{2} / \mathrm{sec}$. From these value the molecular weight of the enzyme $w_{\text {. }}$ calculated to be about 120,000 according the equation of Svedberg and Erikson ${ }^{71}$.

Absorption spectrum. The absorption spe trum of crystalline acid phosphatase w. taken with a Shimazu Model MPS-50 L re ording spectrophotometer (Fig. 6). Over tl wave length investigated, the enzyme e

7) A. Ehrenberg, Acta Chem. Scand., 11, 1257 (195: 


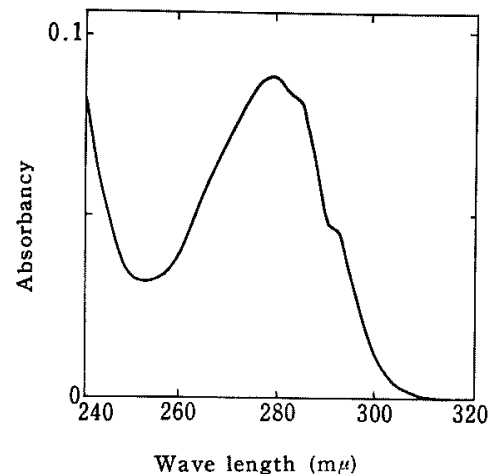

FIG. 6. Ultraviolet Spectrum of Phosphatase

The enzyme solution contained $132 \mu \mathrm{g}$ per $\mathrm{ml}$

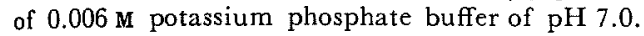

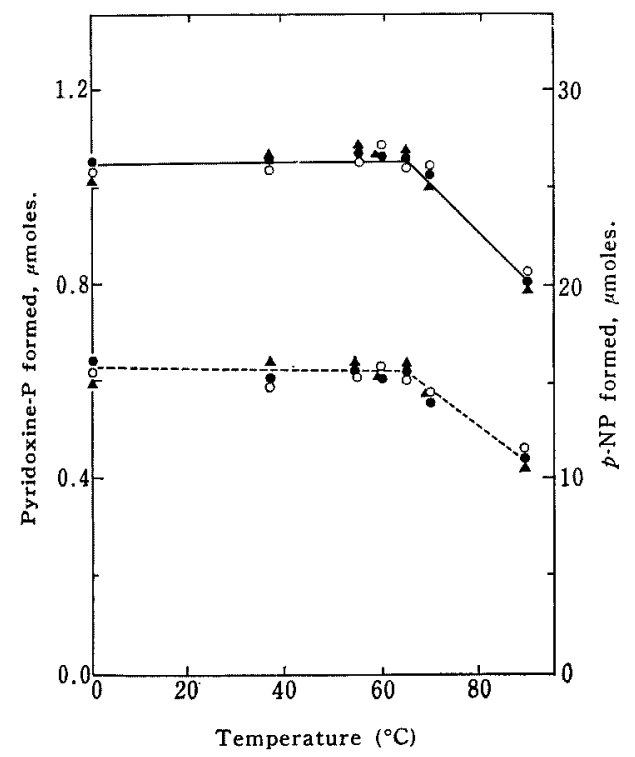

FIG. 7. Heat Stability of the Phosphatase

The enzyme $(18 \mu \mathrm{g})$ was heated for $10 \mathrm{~min}$ at each temperatures in $0.02 \mathrm{M}$ Tris-maleate buffer of $\mathrm{pH} 5.85(\mathrm{O}), 7.00(\mathbf{O})$ and $8.20(\boldsymbol{\Delta})$, and the residual activity was measured under the standard assay conditions.

- $\quad p$-NP formed. .....; pyridoxine-P formed.

hibited the maximum at $279 \mathrm{~m} \mu$. The shoulders at 285 and $293 \mathrm{~m} \mu$ were also noted in the spectrum. The ratio of $260 \mathrm{~m} \mu / 280 \mathrm{~m} \mu$ was 0.52 .
Heat stability. The purified enzyme was heated in a water bath for 10 min with temperature indicated in Fig. 7, and then the residual activity was measured. The enzyme was found to be stable up to 60 to $65^{\circ} \mathrm{C}$, but, above $70^{\circ} \mathrm{C}$, it was gradually destroyed. It was also observed that both the enzyme activities of phosphatase and phosphotransferase were to be parallel on the heat-resistant property.

Substrate specificity. Seventeen phosphoryl compounds were tested as substrates for the phosphatase and phosphotransferase activities of the purified enzyme under the conditions of the standard assay (Table II). The specificity of the enzyme for both the reaction was found to be fairly broad and to be almost similar. Various sugar phosphates and $5^{\prime}$ mononucleotides other than phenolic compounds were readily served, but $2^{\prime}\left(\& 3^{\prime}\right)$ mononucleotides were slightly effective as the substrate for the enzyme.

TABle II. Phosphoryl Donor Specificity

\begin{tabular}{|c|c|c|}
\hline Donor Substrate & $\begin{array}{l}\text { Pyridoxine-P } \\
\text { formed* }\end{array}$ & $\begin{array}{l}\text { Inorganic-P } \\
\text { formed* }\end{array}$ \\
\hline$p$-NPP & 0.43 & 19.5 \\
\hline Phenyl-P & 0.31 & 16.2 \\
\hline Glucose-1-P & 0.03 & 1.8 \\
\hline Glucose-6-P & 0.14 & 4.5 \\
\hline Fructose-6-P & 0.15 & 6.0 \\
\hline Fructose-1, 6-P & 0.15 & 14.6 \\
\hline$\beta$-Glycero-P & 0.02 & 7.8 \\
\hline$\alpha$-Glycero-P & 0.11 & 4.1 \\
\hline $5^{\prime}$-Adenylic acid & 0.05 & 1.3 \\
\hline 5'-Cytidylic acid & 0.03 & 5.7 \\
\hline 5'-Guanylic acid & 0.11 & 5.4 \\
\hline 5'-Inosinic acid & 0.13 & 10.9 \\
\hline $5^{\prime}$-Uridyric acid & 0.14 & 10.8 \\
\hline $2^{\prime}\left(3^{\prime}\right)$-Adenylic acid & 0.00 & 0.0 \\
\hline $2^{\prime}\left(3^{\prime}\right)$-Cytidylic acid & 0.00 & 0.0 \\
\hline $2^{\prime}\left(3^{\prime}\right)$-Guanylic acid & trace & 0.7 \\
\hline $2^{\prime}\left(3^{\prime}\right)$-Uridyric acid & 0.00 & 0.0 \\
\hline ATP & 0.03 & 0.9 \\
\hline Acetyl-P & 0.25 & 15.0 \\
\hline
\end{tabular}

\section{* $\mu$ moles}

The enzyme assay was carried out under the standard conditions with purified enzyme preparation (18 $\mu \mathrm{g}$ of protein) without $p$-NPP. The phosphoryl donor substrate added was $50 \mu$ moles. 
Michaelis constant. The effect of various concentration of substrates, $p$-NPP on the phosphatase activity and pyridoxine on the phosphotransferase activity, was examined as shown in Fig. 8. The Michaelis constants as calculated by the method of Lineweaver and Burk $^{81}$, were found to be $1.7 \times 10^{-4} \mathrm{M}$ for $p$ NPP and $2.6 \times 10^{-1} \mathrm{M}$ for pyridoxine.

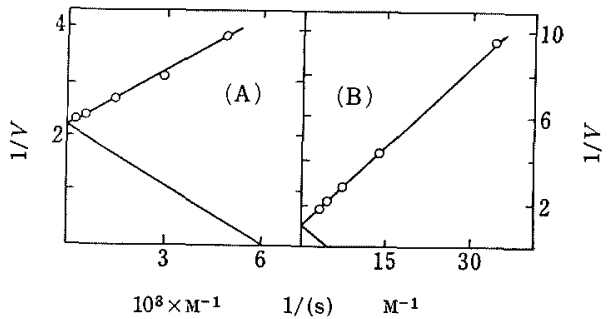

FIG. 8. Effect of Substrate Concentration, (S), on the Reaction Rate, $V$, by Phosphatase.

The enzyme assay was carried out under the standard conditions with purified enzyme (18 $\mu \mathrm{g}$ of protein) without substrate concentration. The results are plotted by the method of Lineweaver and Burk ${ }^{8)}$. (A); $p$-NPP, (B); Pyridoxine.

\section{DISCUSSION}

Although the purification of phosphatase has been attempted by many workers, the enzyme has never been crystallized, nor have purified preparations been demonstrated to be completely free of other contaminating proteins, until recent work on the crystallization of alkaline phosphatases of Escherichia coli ${ }^{9}$ and Bacillus subtilis ${ }^{101}$ These crystallization procedures contained the release of the enzyme bound in insoluble fractions of the organisms by the conversion of cells to spheroplasts or the extraction with a high concentration of magnesium ion. The transphosphorylation catalyzed by alkaline phosphatase have been

8) H. Lineweaver and D. Burk, J. Am. Chem. Soc., 56, 658 (1934).

9) M. H. Malamy and B. L. Horecker, Biochemistry, 3, 1893 (1964).

10) K. Takeda and A. Tsugita, J. Biochem., 61, 231 (1967). reported with purified enzyme preparation ${ }^{11,12}$ but the investigation with the crystalline en. zyme have not been performed. While, several reports on the purification of acid phosphatase have been made ${ }^{13,14}$, success in complete purification has not yet been reported.

The present investigation described the first successful crystallization of acid phosphatase of the isolated bacterial strain, Escherichia freundii $\mathrm{K}-1$. It has been recognized that the acid phosphatase of Escherichia coli was easily solubilized upon disintegration of the cells and that the activity might be separated into several fraction which had different properties $^{15}$ The purification procedures of the acid phosphatase presented herein was performed using cell free extract (sonicated) as starting material. When the acid phosphatase activities of the intact cells and the extract were compared, no difference was found. From the results of the elution patterns on column chromatographies and substrate specificities on the purification steps, the separation of the enzyme activity could not be observed. The purified preparation showed the optimum $\mathrm{pH}$ of 6.0 with $p$-NPP as phosphoryl substrate, differed from that of Escherichia coli ${ }^{16)}$

The purified enzyme preparation also hydrolyzed various phosphates other than $p$-NPP as shown in Table II, and accompanied with the transphosphorylation of pyridoxine under similar $\mathrm{pH}$ range. Though the Neurospora acid phosphatase which has been studied in detail on the substrate specificity had the similar optimum $\mathrm{pH}^{17}$, the Escherichia enzyme utilized the substrates with a somewhat dif-

11) I. B. Wilson, J. Dayan and K. Gyr, J. Biol. Chem., 239, 4182 (1964).

12) J.G. Georgatsos, Arch. Biochem. Biophys., 121, 619 (1967).

13) P. B. Hudson and M. London, ibid., 46, 141 (1953).

14) C. A. Vernon, J. Gauldie, J. M. Hanson, J. M. Humphreys, P. E. Smith, A. J. Lawrence and B. E. C. Bands, Nature, 208, 383 (1965).

15) D. Roger and F. J. Reithel, Arch. Biochem. Biophys., 89, 97 (1960)

16) B. V. Hofsten, Biochim. Biophys. Acta, 48, 17 (1961). 
ferent rate from the phosphatase.

The physiological function of acid phosphatase is still obscure in despite of its widespread occurrence in animal, plant and microorganism. Hofsten ${ }^{161}$ has reported that the acid phosphatase of Escherichia coli was not repressed by inorganic phosphate and the enzyme content of cells grown on carbohydrates was very much lower than that of cells metabolizing organic acids, suggesting the metabolic function. A more anabolic function of the enzyme is, however, not excluded in view of the transferase activity observed for various phosphatases ${ }^{18)}$, which might occur with a competition at the enzyme between

17) M. H. Kuo and H. J. Blumenthal, Biochim. Biophys. Acta, 52, 13 (1961).

18) M. R. Atkinson and R. K. Morton, "Comparative Biochemistry", Vol. II, Academic Press, New York, 1960, p. 1. the acceptor alcohol and water for the phosphoryl moiety from the donor substrate $e^{19}$ The transphosphorylation of vitamin has been investigated using the partially purified preparations of the phosphatase $\mathrm{e}^{20,21}$ or phosphotransferase $^{221}$ In these cases, the identities of the phosphatase and phosphotransferase activities are not be elucidated. In the experiment with Escherichia freundii K-1 reported here, it was recognized with the obtaining of crystalline enzyme that the transphosphorylation of vitamin $B_{6}$ might be catalyzed by the action of phosphatase.

19) R. K. Morton, Biochem. J., 70, 150 (1958).

20) K. Yagi and J. Okuda, Nature, 181, 1663 (1958).

21) S. A. Kumar and C. S. Vaidyanathan, Biochim. Biophys. Acta, 73, 98 (1963).

22) H. Katagiri, H. Yamada and K. Imai, $J$. Biochem., 46, 1119 (1959). 